Sherrill Grace

University of British Columbia, Vancouver

\title{
Timothy Findley, His Biographers, and The Piano Man's Daughter
}

\section{ABSTRACT}

In this paper, Sherrill Grace, Findley's biographer, will examine her biographical practices in the context of Findley's own memoir, Inside Memory, and his interest in creating fictional auto/biographers and auto/biography in several of his major novels (notably The Wars, Famous Last Words, The Telling of Lies, and The Piano Man's Daughter). His fictional auto/biographers often use the same categories of document that Findley himself used-journals, diaries, archives - and this reality produces some fascinating challenges for a Findley biographer, not least the difficulty of separating fact from fiction, or, as Mauberley says in Famous Last Words, truth from lies. Like many writers, Findley kept journals all his life, and they are a key source of information for his biographer; however, his way of recording information and his creation of fictional journals means that a biographer (like the readers of his fictional auto/biographers) must tread carefully. While not a theoretical study of auto/ biography, in this paper Grace will offer insights into the traps that lie in waiting for a biographer, especially when dealing with a biographee who is as self-conscious an auto/biographer as Findley.

Keywords: Timothy Findley, AutoBiography. 
"What makes biography so endlessly absorbing is that through all the documents and letters and witnesses, the conflicting opinions and partial memories, we keep catching sight of a real body, a physical life.”

(Lee 2)

"This is the story of everything I know. Of who we are. And how we lived. And where we come from."

(Findley, The Piano Man's Daughter 537)

\section{Biography AND Autobiography}

Full disclosure: Timothy Findley (1930-2002) was a Canadian novelist, playwright, short story writer, essayist, and autobiographer, and I am Findley's biographer. I have, therefore, access to documents and information not available to other readers, and much of what I am about to say would not be known to the reader who picks up The Piano Man's Daughter (1995) for the first time. If you prefer to discover a novel without the baggage of background facts, then stop reading this essay now and get the novel. If the backstage machinery and facts fascinate you and enrich your discovery, then read on.

Biography and autobiography were very important to Findley. $\mathrm{He}$ kept journals and diaries through most of his life; he published one memoir, Inside Memory, was preparing another, Journeyman, when he died, and gave numerous interviews in which he stressed the impact of certain people and events on his own and his family's life. Most important for understanding his published work, however, is the fact that he so often created fictional biographies and autobiographies, with fictional biographers and autobiographers. Moreover, he sometimes merged the two genres, blurring the lines between them to demonstrate that a life story cannot be told without revealing the teller's life; he understood that, as Paul John Eakin explains, we live "relational [lives] developed collaboratively with others, often family members" (How Our Lives Become Stories 57). Over the past forty years, much scholarly attention has been given to theorizing biography and autobiography, but the artists got there first-from Proust to a host of contemporary writers, and Findley knew about relationality without reading any of the theorists. ${ }^{1}$ Inside Memory is unique in the sense

1 This discussion of the novel owes a great deal to my reading in autobiography theory, memory studies, and to biography theory. For a selection of works I have found most useful, see Atlas, Bruss, Couser, Derrida, Eakin, Egan, Erll and Nünning, Grace (Inventing Tom Thomson), Kirmayer, Lee, Lejeune, Ricour, and Smith. 
that Findley tells us about himself by telling stories about other people who made an impact on his life and who he can never forget. He tells us that he remembers scenes and places, not in objective terms but because he is part of the light or the atmosphere or the sounds and words that included him.

Several of his novels function as some form of fictional AutoBiography (a term I will use to describe his blurred life-story strategy); the main character keeps a journal or writes a diary and saves his or her letters, photographs, and other memorabilia, or, the main character relies on another's memory archive to reconstruct that person's life, and in the process discovers his or her own life. For example, The Wars (1977) contains a biographical story created by a nameless narrator, who is Robert Ross's biographer; there would be no novel without this biographer. The distinction between the biographer and Robert Ross, however, is clear because the biographer is researching his subject decades after Robert died. On this level of the narrative there is no AutoBiography, but The Wars contains two intertextual witnesses who knew Robert and recall their memories of him. One of these witnesses is the Canadian nurse, who received his badly burned body at her nursing station and resented the presence of the Military Police who guarded him as if he were a criminal capable of escape. Marian Turner does not see Robert as crazy or criminal for rebelling against orders and killing a superior officer; she sees Robert as sane, and she offers him enough morphine to end his suffering. When he declines her offer, saying simply "not yet" (Findley, The Wars 189), she takes his words as an indication of his courage and steadfastness. Nurse Turner tells us little about herself apart from the unforgettable impact Robert has had on her life, but the other intertextual witness, Lady Juliet d'Orsay, confesses as much about herself as she does about Robert when the biographer interviews her. She describes herself as a "Boswell in bows" (143), and reads long sections from her diaries into the biographer's tape recorder. Lady Juliet's diary is a fine, if limited, example of fictional AutoBiography, and she represents Findley's first use of this strategy in his fiction.

Famous Last Words (1981), a more ambitious, complex text and, in my opinion, Findley's masterpiece, is a full-fledged AutoBiography written on the walls of an abandoned luxury hotel in the Austrian Alps during the final days of the Second World War. The AutoBiographer is one Hugh Selwyn Mauberley, an American novelist and a Fascist sympathizer, who is wanted by the Americans for treason and by the Nazis because he knows too much about other powerful fascists who plan to slip through the post-war Allied net. One of the two American officers who reads his writing and reacts to it certainly believes the story to be trustworthy and 
sincere; the other officer condemns Mauberley and classifies his so-called confession as a lie, a cynical attempt to exonerate himself. Readers are left to decide for themselves, but before rushing to conclusions they would be wise to reflect on Mauberley's own warning, written as an epigraph for his life-story: "All I bave written here is true: except the lies" (Findley, Famous Last Words 59). The points at which Mauberley has lied about himself or about the others who are inseparable from his life-story, we can never know. One example illustrates this problem well. A key figure in Mauberley's life is the infamous Wallis Simpson, the Duchess of Windsor. Mauberley meets Wallis when they are young and he follows and helps her as her life unfolds during the late thirties and the war. Of course, we must picture Wallis (a real person) as Mauberley (a fictional character) recreates her-ruthless, ambitious, impeccable in her dress, jewelry, and parties, and a fascist sympathizer like her husband-but when we turn to the facts and the historical record, we find that Mauberley's biography of Wallis hews close to what her real biographers and historians tell us. So where are the lies, where the truth? And where, precisely, do biography (of Wallis, who Mauberley adores) and autobiography (Mauberley's own life-story, with all its probable obfuscations, selective remembering, and strategic editing) overlap? ${ }^{2}$

Three of Findley's lesser known works, The Telling of Lies (1986), You Went Away (1996), and Pilgrim (1999) also involve autobiography, biography, and AutoBiography. The heroine and narrator of the first of these novels solves the mystery of a murder, but in the process she reveals significant events in her own life and in the lives of others; her textual modus operandi is the diary she keeps and we read. You Went Away is a moving novella about a family that is falling apart during the Second World War. The first-person narrator who addresses the reader explains that he has found a box of old photographs and is trying to decipher who the people in the pictures are and what happened to them. We know nothing about this narrator, except that he is struggling to create a meaningful story. What Findley knew, and hints at, is that the story the man creates from old photographs is very close to an early period in Findley's own life. ${ }^{3}$ Pilgrim was Findley's last major novel and it warrants its own exclusive attention, but suffice it to say here that a private journal plays a key role in the novel, and sections of this journal are transcribed within the main narrative; indeed, they are so important that they supersede other narrative

2 For studies of Famous Last Words, see Bailey, Brydon, Gabriel, and Scobie.

Set during the Second World War, the novella presents a boy's perspective on his parents deteriorating marriage, his father's alcoholism, and on his father's rejection of him. 
elements in the text. Within the journal we read autobiographical stories about the man who keeps these journals and biographical stories about several others.

Clearly, Findley's fictional biographers and autobiographers are complex, often unreliable, characters. They play central roles in his novels and they always challenge the reader to separate fact from fiction, truth from lies, and one person's life-story from another's. There is, however, one sense in which these characters are utterly reliable. They always stress their problems with the basic materials with which they must work-those documents, witnesses, conflicting opinions, and "partial memories" that Hermione Lee mentions. To Lee's list I would add (from experience) that any reader of a Findley novel must wrestle with the intricate web spun by a fictional biographer or autobiographer whose narrative blurs the boundary between the two genres and who deliberately incorporates aspects of Findley's own or his family's life in their stories. But my chief topic here is The Piano Man's Daughter and Findley is nowhere more autobiographical and AutoBiographical in his fiction than in this novel.

\section{Giving Lily Kilworth a Voice: The Piano Man's Daughter}

Findley conceived of The Piano Man's Daughter as a companion to The Wars. Where the latter drew on aspects of his Findley family's lives, most notably on an uncle who had been a decorated First World War officer, in this new novel he turned to his mother's family for inspiration, factual details, and stories. In The Piano Man's Daughter the key source of inspiration for the character of Lily Kilworth, Charlie's mother, was Findley's aunt, Ruth Bull Carlyle (1893-1984), about whom I shall have more to say. The firstperson narrator of the novel is Charlie Kilworth, and Charlie's mission is to tell his mother's life-story, which means he must find and tell his own. Lily Kilworth is the piano man's daughter, but her father, Tom Wyatt, was killed in an accident before he could marry Ede Kilworth, Lily's mother, and Ede's story is one of the relational lives that contribute to both Lily's and Charlie's life-stories (see fig. 1). When Findley has Charlie tell us, towards the end of the novel, that " $\mathrm{t}]$ his is the story of everything I know" (Findley, The Piano Man's Daughter 537). about his mother's and his own family, about who they all were and where they lived, he is assuring us of the truth of the complicated AutoBiography we have just read; he needs us to see him as a reliable narrator, unlike Mauberley, who we are wise not to trust entirely. In ways I will describe, Charlie repeatedly reminds us that he is trying his very best to give us all the information he can find in the clearest, most honest terms possible. 
Charlie's prime motivation for telling us his story is his passionate need to make amends to a mother he adored but felt he had betrayed. Lily Kilworth is an unusual mother and her story is heartbreaking. Not only is she born in 1890 as an illegitimate child, but she is also born with a terrible illness inherited through her mother's family. From the age of three she had suffered epileptic seizures, but worse still she heard the voice of a mad relative that loomed out of fire places and she grew up to be both terrified of this man's voice and a pyromaniac. After she suffered a seizure in front of her mother's husband, Frederick Wyatt, and a group of wealthy dinner guests, she was locked in the attic every time her family entertained. Lily hated her mother's husband and refused to recognize the man as a father or to use the name Wyatt. Beautiful and brilliant, Lily spent two years in England in her early twenties, and that is where she conceived her son, Charlie. However, Lily cannot remember who Charlie's father was because this man had rescued her during one of her attacks and she had clung to this stranger until forcibly removed from him. In this way, Charlie's decision to tell Lily's story is also motivated by his desire to identify his father for both his and Lily's sake.

By the time he does learn his father's identity, however, it is the fall of 1939, another war is coming, and Lily has died on 17 July 1939 in the fire that destroyed the Asylum for the Insane at Whitby, Ontario, in which she lived. Lily had been confined to this asylum after her breakdown in 1918, and this collapse was precipitated by the news that her lover, Neddy Harris, the father of her unborn child had been killed on the last day of the war. Consumed by despair, Lily had tried to kill herself by burning down the movie theatre in which she had first met Neddy, but she was saved by an eight-year-oldCharlie. Lily was immediately committed to the infamous Queen Street Asylum for the Insane in Toronto, where she attacked her son on his first visit and where she later gave birth to a stillborn daughter. Lily believed that by saving her life, her son had betrayed her, and Charlie believes that he must atone for her terrible life after her incarceration as a dangerously mad person and her years of slow and partial recovery. He has never thought of his mother as crazy, and he sees her treatment as appallingly wrong. To Charlie, Lily is unique, full of imagination and talent, beautiful and loving of nature and all other creatures. She could also be a frightening woman who, at times, would insist that they flee into the night from wherever they were staying because the voice in the fire was calling to her. As a child, Charlie could not understand what was happening to his mother at such times, except that she was terrified and wanted to save them both.

If there is anything positive about the fire in which Lily dies, it is that Charlie retrieves her wicker suitcase, which survived the flames and contains his mother's notebooks, photographs, letters, and other memorabilia. This suitcase, then, holds the basic archive with which Charlie must work to 
reconstruct the story of Lily's life. And he begins her story in his pre-Second World War present of July 1939 by telling us that "some of what follows I lived and some was told to me" (6) and that the parts he passes on to us "about Lily's family and the men she loved ... were written in Lily's notebooks, or told to me by others" (7). Charlie's archive, then, is as complete as possible and he can supplement what is not in the suitcase from his own experiences and with what others recall. Chief among these people are his grandmother, Ede, and his maternal great-grandmother Eliza Fagan Kilworth. To grasp the meaning of Lily's existence, he must know the root of her illness and how her mother and grandmother handled such a catastrophe. Eliza is the one who passes on the factual information about inherited madness in the Fagan family because it was her uncle, John Fagan, who had the "falling sickness" and eventually burned down the family home in Dublin, killing himself and Eliza's grandparents. Genealogy matters hugely in this story, and the tragedy of Lily's life bears close resemblance to a tragedy in Findley's own family.

Findley once insisted that, although he had drawn heavily on his mother's family to create The Piano Man's Daughter and dedicated the novel "in memory of my Aunt Ruth," Lily was not Ruth and he was not Charlie. In a 29 April 1998 fax to his German publisher, Doris Janhsen, he explained that "the most pertinent personal background" to the novel concerned pianos-playing them and making them-because his mother's father, Frederick Bull, had sold pianos and owned a piano factory, and everyone in the Bull family played pianos, including Findley himself. However, a closer reading of the novel that is informed by Findley's biography makes clear that in the character of Lily Kilworth he was attempting to give his Aunt Ruth, a woman he adored and believed to have been abused by her husband and the medical profession, the voice she had been denied during her lifetime. Ruth had wanted to be a writer-she had published poetry-but she was a schizophrenic in an era that did not understand this illness and dealt with such women by sedating them and incarcerating them so they would not be an embarrassment to their families. Ruth was committed on her husband's orders and for many years Findley was not allowed to see her because the family considered her mad. Findley was technically correct, of course, in his letter to Jahnsen because fictional characters are not the same as real people. Lily is an invention, as is Charlie, but their function is to tell us an AutoBiography that Findley creates from personal experience, deep emotional attachment, and his family's history. ${ }^{4}$

Ruth Bull was Findley's mother's sister and he "adored" her. In Journeyman, he describes her as a "wonder ... a medium, a mystic" (91), as

4 Several other characters bear some resemblance to Bull family members, and Timothy Findley had a father, who played an important role in his life. 
well as a woman with schizophrenia who spent over half her life in asylums. On rare occasions as a child, he was taken to see her in the Whitby Asylum, with its lawns, trees, and walls, and he remembered her vividly as "tall, somnambulistic, reticent-and beautiful" (Findley, Journeyman 91). "This is the stuff," he writes, "from which Lily Kilworth was born" (91). In addition to the inspiration he experienced from such seminal images, he decided that Ruth "wasn't going to die without having said a few words aloud, beyond the secrecy of her notebooks and letters" (88). And so, with some modifications, we have Lily, who suffers, Findley explains, from something "closer to autism than schizophrenia" and yet is "the closest I've ever come to attempting a selfportrait" (92). This autobiographical claim comes as something of a surpriseFindley was never diagnosed with a mental illness_-but he goes on to locate the connection between Ruth-Lily and himself in "uniqueness," a quality that sometimes caused Findley considerable despair. ${ }^{5}$ In terms of narrative voice and perspective, however, Findley is much like Charlie-haunted by a powerful, misunderstood woman, and determined to tell her story.

Explicit connections between reality and fiction are established in the novel through the photographs reproduced for the 1995 hardback edition, where the endpapers carry a collage of old pictures, most of which are Findley and Bull family snapshots. Six of these pictures reappear in the novel at the beginning of the "Prelude" and at five of the novel's seven parts. Unfortunately, the paperback edition does not include the collage, but it does retain the six individual images that introduce parts of the book. These six reproductions of faded photographs should prompt a reader to question the relationship between the fictional characters and the real people in the photographs; the collage, however, enhances the connection between real life and fiction, actual people and imagined ones, and stresses the multiple connections between the author's family and the fictional biographer's story. The most important picture is the faded photograph of Findley's mother, Margaret, in a 1920s bathing suit, laughing beside her sister Ruth, who stands between Margaret and their father, Fred Bull. You can find it in the lower lefthand corner of the collage and at the beginning of the "Prelude." These are the real people, or so this old photograph insists, about whom we will read, and the woman in the centre, smiling at the camera, is important (fig. 2).

The Piano Man's Danghter employs an elegiac romance plot in which a narrator tells the story of a person who has died and cannot speak for him- or herself, except through the narrator's story. ${ }^{6}$ Elegiac romances involve a triangulation of characters: the narrator/biographer (Charlie), the

5 I explore these matters fully in Hope Against Despair.

6 The elegiac structure can be found in several novels, notably The Great Gatsby and Fifth Business; see Merivale. 
biographee (Lily), and a third, desired but missing figure, which in this novel is the father-Charlie's father (not known yet), Lily's father (Tom Wyatt, dead), and Lily's stillborn baby's father (Neddy, dead). By creating Lily's life story, Charlie creates his own and the stories (from what is known) about these fathers. The Piano Man's Danghter is, then, a quest novel, structured as an elegiac romance, and told as a fictional AutoBiography.

In Charlie's words, "I will give her back her life" (Findley, The Piano Man's Daughter 13), and he begins by putting his biographer's cards on the table and addressing us: "I will tell you about" (7), "I will tell you honestly" (8), "[y] ou already knew my father had disappeared" (9), "I am Charlie Kilworth, Piano Tuner. .. . You may well have heard of the Wyatt Piano Company. Perhaps you own a Wyatt yourself” (9). And he confesses that on one occasion he had disowned his mother; she had fallen to the ground and, rather than admit that he knew this woman having a seizure in public, he ran away, hoping she would not die because he would then have to "claim" her (13). With these opening assurances, and the visual corroboration of family photographs, Charlie not only claims Lily, he claims our attention and our trust. But he goes further. As he opens Lily's wicker suitcase, he describes each object-her notebooks, photograph albums, letters, a jewelry box containing a wreath of grasses and flowers, a jar of stones, a box of matches, and a boy's sun suit on which Lily had embroidered the name, Charlie. We see each item (and hopefully remember them because each plays a role in Lily's life), and we can relate to them, especially if we also preserve such personal treasures. When Charlie tells us that he can detect her perfume emanating from the opened suitcase, we believe that what we see through his eyes and words really are "Lily's familiars, her totems ... her songs" (12) and that Lily believed each of her things "had its own voice" (12). We are, in short, hooked by the time we have opened the book and read the first dozen pages.

Although Charlie often seems to disappear beneath an authoritative, traditional third-person voice and focalization, he surfaces repeatedly to remind us that this voice is, in fact, his. The first such voice shift occurs at the start of part one, "1889-1890," which is introduced by a picture of a woman in a garden, presumably the character Ede, who we meet in this section and who was pregnant with Lily. ${ }^{7}$ Charlie is describing this and other photographs for us, giving us their dates (if they carry dates), and telling us that he is there

7 This photograph is of Edith Maude (Fagan) Bull, Findley's maternal grandmother, dated by Findley as 1908; it is a profile shot of a pretty woman with short hair and a full white blouse; she is smiling and reaching out to some bushes in a garden. The original photograph is held, with other family photographs, in the Findley/Whitehead fonds at Library and Archives Canada (LAC). 
in one photograph: "I am there in Lily's womb. The date is August 1910. I will be born the following October" (18). Then, almost imperceptibly, Charlie's personal voice and perspective shift as he slips into his more formal biographer's voice to describe Ede giving birth to Lily in the corner of a field near her family's farm at Munsterfield, at the exact spot where Lily had been conceived: "It was in [Ede's] mind that she would create a wreath of those flowers and grasses from the field" (24). We are told this because Ede told Lily and both his grandmother and his mother told Charlie about this wreath (kept in the wicker suitcase) and about Lily's conception and birth. Charlie could not possibly reconstruct such private events without evidence, and he surfaces several pages later to assure us that he "found scribbled notes," written by Ede in her diary and preserved by Lily $(66-67,71-72)$.

Another striking instance of Charlie's surfacing from beneath the objective voice occurs when he explains why Lily hated Frederick from the moment he arrived at Munsterfield to court Ede. "She told me this herself," Charlie tells us, that on first sight Frederick "terrified" her because he had cold eyes when he smilingly insisted that she come to him to be kissed. Lily was only six at the time, but she refused, and Charlie "watched [her] conjuring the moment": "I might have been seven or eight years old when she told me this story," he says, and the scene Lily evokes is "straight out of David Copperfield. Mister Murdstone had risen from its pages and forced himself into [her] life" (126). Of course, it is Frederick and Lily who have just risen from the pages of Charlie's biography, where we (as Hermione Lee claims good biography will) catch sight "of a real body, a physical life" (Lee 2). And if we have read Dickens, the terror called up by the reference will be even greater.

On many occasions, such as this Dickensian encounter between Frederick and young Lily, Charlie quotes his mother, either from the stories she told him, their conversations, or her notebooks. Lily's voice appears in italics as she interrupts Charlie's first and third person narration. Charlie also quotes his great-grandmother, Eliza, without using italics and, on one occasion, Eliza tells Ede, who in turn tells Charlie, "The Story of John Fagan" (132). This story is an essential key to our understanding of Lily and Charlie because in 1843, John Fagan set fire to the family home in Dublin and he and Eliza's grandparents perished. Uncle John had been locked in the attic because he had visions, spoke with God, and wrote on the attic walls. The writing on the walls was "all about death" and fire, and the words were "decorated with leaves and bees and singing birds" (134-35). ${ }^{8}$ Lily has

8 In Famous Last Words Mauberley is explicit about the biblical reference to the Book of Daniel. No biblical allusion is made in The Piano Man's Dangbter, but a well-read reader will catch the allusion. 
inherited this genetically transmitted illness and John's story is integral to hers; moreover, Charlie refuses to father a child for fear that it too would be afflicted. Biography overlaps, in the genes and the stories, with autobiography to establish the lynchpin in Charlie's AutoBiography. The story of Uncle John, however, finds its source well outside the pages of The Piano Man's Daughter in Findley's family and his Aunt Ruth not, to be sure, in its details, but in the situation, the misunderstanding of and cruel response to mental illness, and the fear it evokes in those who can only see madness and danger in the visions and behavior of such uncles and aunts. The generic blurring of biography and autobiography within the novel extends to a blurring of distinctions between fact and fiction, imagined characters and real people, between fictional AutoBiography and the Findley/Bull/Fagan story in which Timothy Findley's maternal ancestral story contains a Fagan line and an Aunt Ruth.

As Charlie gets older, he feels better able to tell us Lily's story without relying on others. From about the age of five or six, he becomes a remembering, participating eyewitness to her life, her escapes, her terrors, and her joy in music, movies (she names him for Charlie Chaplin), nature, and love. In the wicker suitcase he finds notebook entries "addressed" to him (213), and he tells us about the times he and Lily studied her photograph albums in an effort to identify his father. This shared search for the lover/ father enables him to include more and more of his autobiography into Lily's biography until he finally tells the story of his adult life, career, marriage, and visits to Lily at Whitby (276 and 378-79). Thanks to the gift inherited from Lily's pianist father (Tom Wyatt), and the father he has yet to discover, Charlie possesses perfect pitch and becomes a pianist and piano tuner, not a maker of instruments like his Wyatt relatives. For the story of piano manufacture and sales in turn-of-the- $20^{\text {th }}$-century Ontario, Findley drew upon the lives of his maternal relatives; the Bull father and sons were all musicians and involved in the business, none more so than Findley's grandfather Bull. As Findley told Doris Jahnsen, pianos were the strongest autobiographical link in the novel. But that is where the connections between Charlie's life and Findley's ancestors ends because when Charlie learns who his father was, the discovery is a fictional surprise.

\section{Reflections on a Suitcase}

Just before Charlie discovers his father's identity, he raises an important question, one that all respectable biographers and autobiographers should consider. "Something must be said about our finances," he remarks: "If I were reading this, I would want to know where their money came from" 
(514). The obvious answer, that it comes from the Wyatt and Kilworth families, will not do because by the 1920 s the piano manufacturing business was failing and the patriarchs of both families soon died. These families no longer had the means to pay for Charlie's private school and Lily's expensive care. Personal finances, Charlie notes, are none of our business, and yet money cannot be ignored "when you're telling the story of someone's life" (515). So back to the wicker suitcase we go for the clue Charlie needs. In a package of statements for his school fees, he finds the school thanking someone by the name of "E. Anderson" (516). This name means nothing to him, but as one thing leads to another (across a chronology that jumps back and forth, much as research does), he and we finally discover that "E. Anderson" is, in fact, Lily's closest Cambridge friend, the wealthy Eleanor Ormand. Eleanor had found Lily after her seizure in 1910, and she later married the German officer who had rescued Lily, Karl Hess. After Hess died in the Great War, Eleanor remarried a Mr Anderson: she is "E. Anderson." However, she withholds her identity and the secret of Charlie's paternity until after Lily's death, when she writes to him with all the details (526-27). She knows that Karl Hess was Charlie's father and because she loved both Karl and Lily, she had watched over Lily and her son after the war. She tells Charlie that he looks like his father, that Karl loved music, and that "Your name is Hess-if you want it" (526).

With these revelations, Charlie's autobiography is almost complete and the missing link in Lily's biography is in place. In a "Coda," Charlie tells us that he fought in the Second World War, was emasculated by a land mine in a field near Ortona in 1943, but had fathered a daughter while on leave with his wife in 1942. The novel ends after the war, when the couple and their daughter visit "Lily's field" to mark the anniversary of Lily's fifty-sixth birthday. The AutoBiography is complete. It has come full circle back to the field where these life-stories began. And Charlie's name, like his mother's and daughter's, is Kilworth. As far as I am aware, no such war injury, no such asylum fire, and no such benefactor exist in Timothy Findley's biography, and I have not located a mad Irish Fagan ancestor who burned down the family home in the 1840s. When Charlie wraps up the stories in The Piano Man's Danghter, he closes his work as a fiction. He has created what Lee would call an "endlessly absorbing" biography of his mother, brought her to life, and told us all he knows about the Fagans, Kilworths, and Wyatts. Along the way, he reveals a good deal about social class, social prejudice, rural and urban life in southern Ontario between 1890 and 1946, about the treatment of mentally ill women, the rise and fall of piano manufacturing, and inevitably about himself and about Lily's shaping influence on his life. 
The result is a rich AutoBiographical novel. It is also a novel in which archives matter. Most of Findley's novels contain archives; The Wars is an obvious example because that is where Robert's biographer begins- "in the archive" (11). The archive in The Piano Man's Daughter is more personal, more akin to the memorabilia that many families keep and pass along to future generations, and rather more unusual. The wicker suitcase that Lily always carries with her when she travels or when she escapes with Charlie into the night to flee her demons, is Charlie's main source of information. It is invaluable; without it Charlie could not tell Lily's story or quote Lily's words for us or discover important details about his own life. This suitcase is, in a sense, Lily's life, her story. After the fire in which she dies, it is all that is materially left of Lily's life, except, of course, for Charlie. It preserves her identity, her scent, her voice. This suitcase is, then, a symbol of the past, of remembering, of ancestors, places, and events. And we should not overlook the possibility, reinforced by their reproduction in the text, that those photographs in the suitcase are Findley's family photographs, which makes the suitcase a symbolic link between the fiction and reality, between Findley's characters and his own biography.

Although this novel may close as a fiction-after all, it does not reproduce events in Findley's adult life-there are numerous ways in which the facts and people of Findley's biography linger and disturb us after we close the book. We are left wondering where the fiction and the real life diverge. I am also left reflecting on Findley's passionate need to give his Aunt Ruth a voice, to give her some words she could say out loud, to allow her to be heard. Without doubt, Ruth Bull Carlyle haunted Findley and he felt the deepest sympathy for her, but some feminist critics might argue that as a man, even a gay man, he could not speak for/ as a woman and should not presume to try. While I acknowledge that argument, I believe that by speaking through Charlie to ventriloquize Lily, he has brought her character alive and given her a powerful voice. It is in this vividly realized character that we will feel the presence of Ruth and hear her speak. What's more, Findley has broken the silence surrounding mental illness, and he has recreated a convincing period in one area of Canada with such memorable characters that they will haunt the reader, much as Lily haunts Charlie, and as Aunt Ruth haunted Findley. Lily's message to her son was always "pass it on" (537), and that is what he does by calling up the ghost of her irresistible life-force and by urging all of us to remember, to respect all living things, and to sing about the joy of being alive. Which is what Timothy Findley does in The Piano Man's Daughter. 


\section{Works CiTED}

Atlas, James. The Shadow in the Garden: A Biographer's Tale. New York: Knopf, 2017. Print.

---. "The Biographer and the Murderer." New York Times Magazine. 12 Dec.1993: 74-75. Print.

Bruss, Elizabeth. Autobiographical Acts: The Changing Situation of a Literary Genre. Baltimore: Johns Hopkins UP, 1976. Print.

Brydon, Diana. Writing on Trial: Timothy Findley's "Famous Last Words." Toronto: ECW, 1995. Print.

Bailey, Anne Geddes. Timothy Findley and the Aesthetics of Fascism. Vancouver: Talonbooks, 1998. Print.

Couser, G. Thomas. Recovering Bodies: Illness, Disability, and Life-Writing. Madison: Wisconsin UP, 1997. Print.

Derrida, Jacques. "Archive Fever: A Freudian Impression.” Trans. Eric Prenowitz. Diacritics (Summer 1995): 963. Print.

Eakin, Paul John. How Our Lives Become Stories: Making Selves. Ithaca: Cornell UP, 1999. Print.

---, ed. On Autobiography. Minneapolis: U of Minnesota P, 1989. Print.

Egan, Susanna. Mirror Talk: Genres of Crisis in Contemporary Autobiography. Chapel Hill: U of North Carolina P, 1999. Print.

Erll, Astrid, and Ansgar Nünning. "Concepts and Methods for the Study of Literature and/as Cultural Memory." Literature and Memory: Theoretical Paradigms, Genres, Functions. Ed. Ansgar Nünning, Marion Gymnich and Roy Sommer. Tübingen: Francke Verlag, 2006. 11-28. Print.

Findley, Timothy. Famous Last Words. Toronto: Clarke Irwin, 1981. Print. ---. Inside Memory: Pages from a Writer's Notebook. Toronto: HarperCollins, 1990. Print.

---. Journeyman: Travels of a Writer. Ed. William Whitehead. Toronto: Harper Flamingo Canada, 2003. Print.

---. Letter to Doris Jahnsen. 29 Apr. 1998. Timothy Findley/William Whitehead Collection. Box 282-11. LAC.

---. Pilgrim. Toronto: HarperCollins, 1999. Print.

---. The Piano Man's Daughter. Toronto: HarperCollins, 1996. Print.

---. The Telling of Lies. Markham, ON: Viking, 1986. Print.

---. The Wars. Toronto: Clarke Irwin, 1977. Print.

---. You Went Away. Toronto: HarperCollins, 1996. Print.

Gabriel, Barbara. “The Repose of an Icon' in Timothy Findley's Theatre of Fascism: From 'Alligator Shoes' to Famous Last Words.” Paying Attention: Critical Essays on Timothy Findley. Ed. Anne Geddes Bailey and Karen Grandy. Toronto: ECW, 1998. 149-80. Print. 
Grace, Sherrill. Hope Against Despair: A Life of Timothy Findley. Waterloo, ON: Wilfrid Laurier UP, 2019. Print.

---. Inventing Tom Thomson: From Biographical Fictions to Fictional Autobiographies and Reproductions. Montreal: McGill-Queen's UP, 2004. Print.

Kirmayer, Laurence J. "Landscapes of Memory: Trauma, Narrative, and Dissociation.” Tense Past: Cultural Essays in Trauma and Memory. Ed. Paul Antz and Michael Lambek. New York: Routledge, 1996. 173-98. Print.

Lee, Hermione. Virginia Woolf's Nose: Essays on Biography. Princeton: Princeton UP, 2005. Print.

Lejeune, Philippe. "The Autobiographical Pact (bis)." Trans. Katharine Leary. On Autobiography. Ed. Paul John Eakin. Minneapolis: U of Minnesota P, 1989. 119-37. Print.

Merivale, Patricia. "The Biographical Compulsion: Elegiac Romances in Canadian Fiction.” Journal of Modern Literature 8.1 (1980): 139-52. Print.

Ricœur, Paul. Oneself as Another. Trans. Kathleen Blamey. Chicago: U of Chicago P, 1992. Print.

Scobie, Stephen. "Eye-Deep in Hell: Ezra Pound, Timothy Findley, and Hugh Selwyn Mauberley." Essays on Canadian Writing 30 (1984-85): 206-27. Print.

Smith, Sidonie. "Taking it to the Limit One More Time: Autobiography and Autism." Getting a Life: Everyday Uses of Autobiography. Ed. Sidonie Smith and Julia Watson. Minneapolis: U of Minnesota P, 1996. 226-46. Print.

Quotations from Timothy Findley's work and the photograph in fig. 2 appear with the permission of Timothy Findley as author and Pebble Productions Inc. as rightsholder.

Sherrill Grace is an Officer of the Order of Canada, a Fellow of the Royal Society of Canada, and a University Killam Professor Emerita at the University of British Columbia. She has published extensively on Canadian Literature and Culture with books on the Canadian North, Tom Thomson, Sharon Pollock, and Margaret Atwood. She edited the collected letters of Malcolm Lowry and has published four books on Lowry. Her biography of Timothy Findley will appear in 2019.

sherrill.grace@ubc.ca 



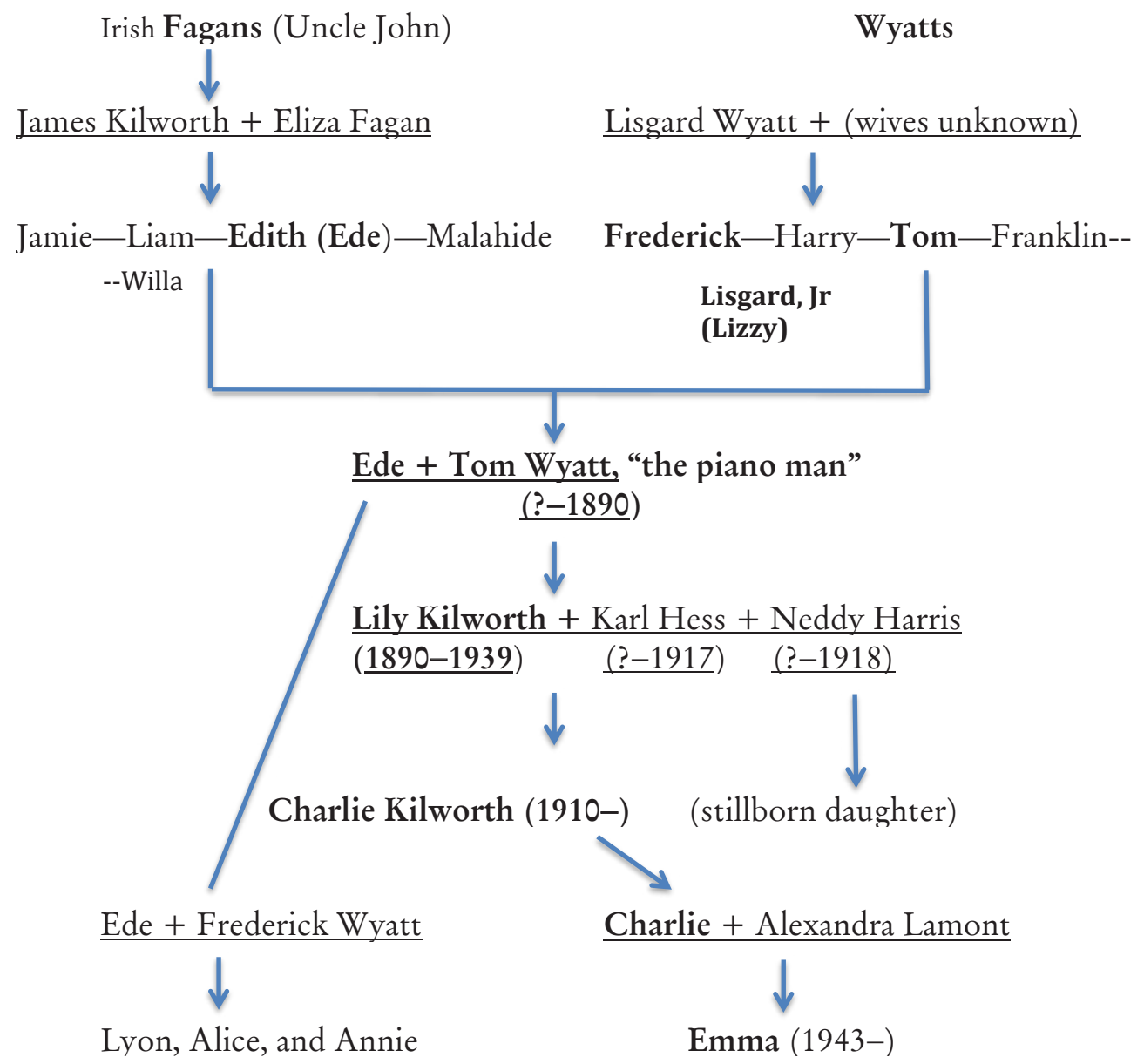

Fig. 1. Fictional genealogy in The Piano Man's Daughter. 


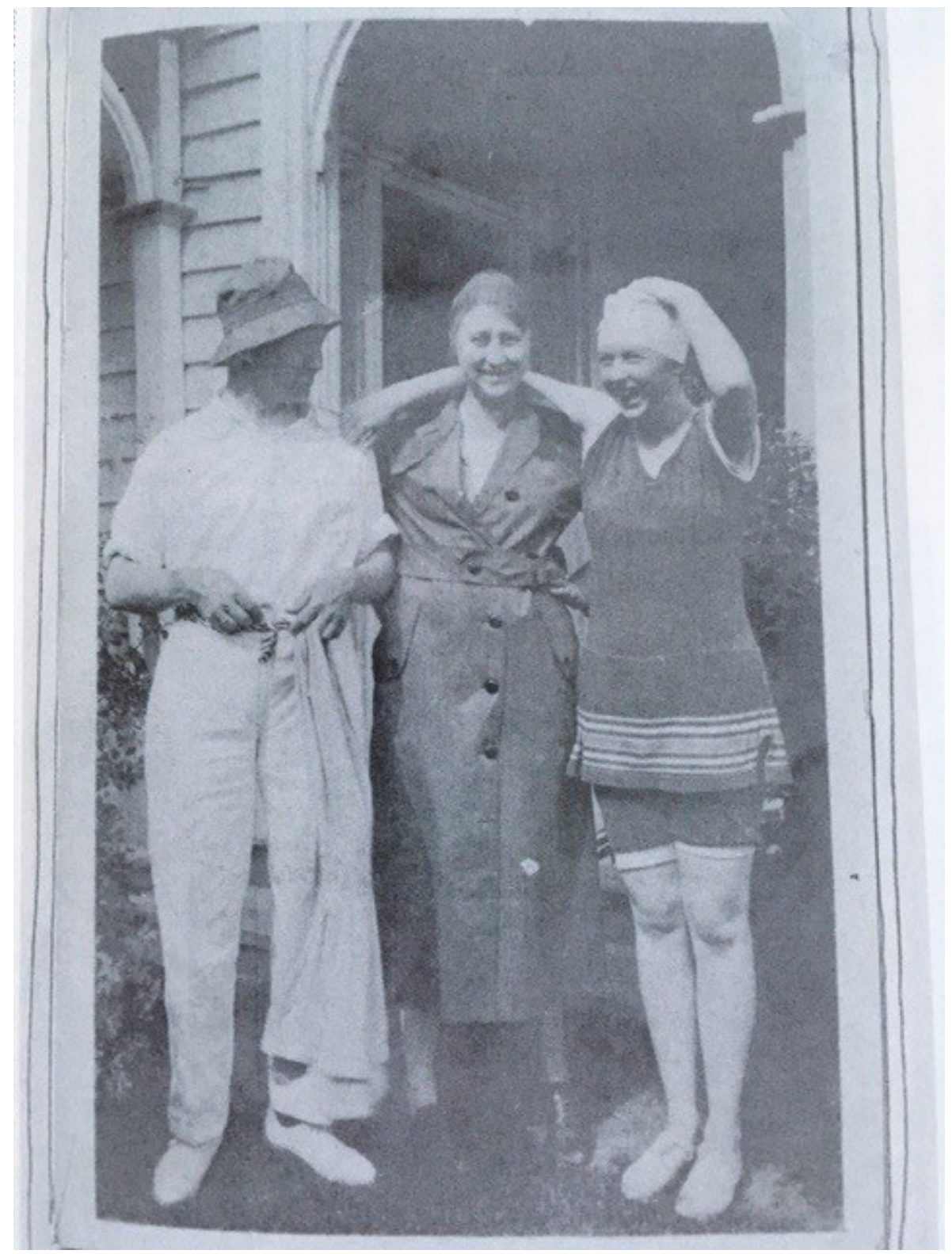

Fig. 2. From left to right, Fred Bull (Findley's maternal grandfather), Ruth Bull Carlyle (Aunt Ruth), and Margaret Bull Findley (Findley's mother). This photograph appears in the endpaper collage for The Piano Man's Daughter. Reproduced from Journeyman (facing page 114). Original is with Findley/ Whitehead fonds, LAC (MG31-D196). 